\title{
TEORIA CENTRUM - PERYFERII \\ IMMANUELA WALLERSTEINA I JEJ RECEPCJA \\ W ARCHEOLOGII
}

\section{IMMANUEL WALLERSTEIN'S CENTRE - PERIPHERY THEORY AND ITS RECEPTION IN ARCHAEOLOGY}

\author{
Adriana Ciesielska \\ Zakład Zasobów Poznawczych Człowieka \\ Wydział Pedagogiczno-Artystyczny \\ Uniwersytet im. Adama Mickiewicza, Poznań - Kalisz, Poland \\ adrianac@wp.pl
}

\begin{abstract}
This paper presents the World-System Theory, which is also called the Centre - Periphery Model, and its application and usefulness in archaeology. This article focuses only on the World-System theory; the World-System Analysis will be discussed elsewhere. In the current article I consider the background to the Theory, its emergence at the beginning of the 1970sand its influence on archaeological works, particularly on the scholarly activity of Kristian Kristiansen and Andrew Sherrat. As an example, I present some statements concerning the Bronze Age as an era that saw very sophisticated, multiple exchange relations connecting remote regions of Europe. I also present the criticism towards the World-System Theory and its application in archaeology by Anthony Harding.
\end{abstract}

KEY WORDS: Centre - Periphery model, world-system economy, Immanuel Wallerstein, Bronze Age, contacts

Artykuł ten ma na celu przedstawienie społeczności archeologicznej dorobku i osiągnięć jednej $\mathrm{z}$ najciekawszych postaci nauk społecznych przełomu XX i XXI w. - Immanuela Wallersteina. Proponowana publikacja będzie podzielona na dwie części, które będą ukazywać się w kolejnych numerach Folii Praehistorici Posnanienses. 
Część pierwsza mojej pracy dotyczy bezpośrednio Teorii systemów-światów I. Wallersteina oraz jej recepcji $\mathrm{w}$ archeologii. Część druga poświęcona będzie w całości analizie systemów-światów, czyli krytycyzmowi, na jaki napotkała koncepcja I. Wallersteina w naukach społecznych i próbom jej modyfikacji, w tym również jej dostosowaniu do archeologii.

\section{CZYM JEST SYSTEM-ŚWIAT (,WORLD-SYSTEM ECONOMY”)?}

Zdaniem I. Wallersteina istnieją trzy intelektualne bloki teorii systemów-światów, są to szkoła Annales, teoria Karola Marksa oraz teoria rozwoju. Bloki te są związane z doświadczeniem życiowym I. Wallersteina i jego podatnością na różne zagadnienia, teorie i sytuacje. Zawierają one, jak pisał sam Wallerstein:

Przesłanki zasady, aby w ten sposób dać pełny obraz perspektywy stanowiącej wezwanie do uprawiania holistycznie pojmowanych historycznych nauk społecznych (Wallerstein 2007,

11) lub nowa perspektywa w badaniu rzeczywistości społecznej” (Wallerstein 2007, 13).

Teoria systemów-światów zawdzięcza szkole Annales, której głównym reprezentantem był Fernand Braudel, jej historyczne podejście. Wallerstein zapożyczył od Braudela jego nacisk na czas długiego trwania (,la longue duree”). On także nauczył się koncentracji na geologiczno-ekologicznych regionach jako jednostkach analizy. Warto w tym miejscu przywołać klasyczną już pracę Braudela o Morzu Śródziemnym, jako wzór takiego postępowania. Następnie poświęcenie uwagi rolnictwu i historii rolnictwa i poleganie na empirycznych materiałach. Wpływ szkoły Annales odbywa się na ogólnym poziomie metodologicznym.

I. Wallerstein zaczerpnął z teorii Karola Marksa przekonanie o fundamentalnej rzeczywistości konfliktu społecznego wśród materialnie usytuowanych grup ludzkich, troskę o istotną całość, przejściowy charakter form społecznych i teorii ich dotyczących, centralność procesu akumulacji i konkurencyjną walkę klas jako jej rezultat, dialektyczny sens ruchu poprzez konflikt i sprzeczność. Intencją Wallersteina było także zrewidowanie samego marksizmu.

Teoria systemów-światów I. Wallersteina jest na wiele sposobów adaptacją teorii zależności. Wallestein wiele zawdzięcza teorii zależności, neomarksistowskiemu wyjaśnianiu procesów rozwoju, popularnych w rozwijającym się świecie, którego główną postacią byli Fernando Henrique Cardoso ${ }^{1}$. Teoria zależności (,,dependence theory") koncentruje się na rozumieniu peryferii przez spojrzenie na relacje między centrum a peryferią. Kwitła ona w peryferyjnych regionach, takich jak Ameryka Łacińska. To z perspektywy teorii zależności wyrasta wiele współczesnych krytyk globalnego kapitalizmu.

\footnotetext{
${ }^{1}$ F.E. Cardoso - z wykształcenia socjolog, brazylijski polityk, I. prezydent Brazylii.
} 
Inne ważne wpływy na pracę I. Wallersteina to w dalszym ciągu obecna we współczesnym świecie teoria Karla Polanyi $(1944,1957)$ i Josepha Schumpetera (1960). Od Schumpetera pochodzi światowe zainteresowanie się cyklami biznesowymi, zaś od Karla Polanyiego pochodzi pojęcie trzech podstawowych sposobów organizacji ekonomicznej: wzajemności, redystrybucji i rynku (sposobu gospodarki rynkowej). Są one analogiami do pojęć Wallersteina minisystemów, światowych imperiów i gospodarek światowych. Jak pisał I. Wallerstein:

Analiza systemów-światów oznaczała przede wszystkim zastąpienie standardowej jednostki analizy, jaką było państwo narodowe, jednostką analizy nazwaną systemem-światem. Ogólnie rzecz biorąc, historycy analizowali dzieje narodowe, ekonomiści - gospodarki narodowe, politolodzy - narodowe struktury polityczne, a socjologowie - społeczeństwa narodowe. Badacze systemów-światów odnosili się do tego sceptycznie, podając w wątpliwość to, czy którekolwiek z tych przedmiotów badań faktycznie istniał, a w każdym razie, czy były to obszary analizy zakreślone w sposób bardziej użyteczny. Zastąpili państwa narodowe, traktowane jako przedmiot badań systemami historycznymi, które, jak stwierdzili, aż do chwili obecnej istniały jedynie w trzech wariantach: jako tzw. minisystemy oraz dwa rodzaje systemów-światów: gospodarki-światy i imperia-światy (Wallerstein 2007, 32-33).

I. Wallerstein zaproponował, aby podstawową jednostką analizy uczynić nie państwo narodowe, ale „world-system”, tłumaczony jako „system-świat”, a właściwie różne systemy tworzące sieć ponadnarodowych powiązań, w których państwa dopiero mogą zaistnieć.

System-świat (,world-system”) to złożona strukturalna charakterystyka syste$\mathrm{mu}$, a nie na przykład wyłącznie sposób produkcji. Stanowi on podstawę wyodrębniania okresów historii społecznej. Wallerstein zamiast o niewolnictwie, feudalizmie i kapitalizmie pisze o różnych systemach-światach czy o nowoczesnym systemieświecie, który od XVI w. wyłonił się w formie kapitalistycznej gospodarki-świata. W Polsce tradycja reprezentowana przez I. Wallersteina istnieje od wielu lat. Reprezentacyjnym dziełem jest trzytomowa praca Fernanda Braudela Kultura materialna, gospodarka i kapitalizm. F. Braudel w t. 3 zdefiniował i rozwinął kategorię gospodarek-światów. Zawarta jest w nim rekonstrukcja zasadniczych poglądów Wallersteina oraz thumaczenie używanej przez niego terminologii w pełni zasługuje na miano kanonicznego (Starnawski, Wielgosz 2007). Dla Wallersteina system-świat to system społeczny, taki, który ma granice, struktury, grupy członkowskie, prawa legitymizujące i spójność. Na jego życie składają się siły znajdujące się w konflikcie, które trzymają go razem przez napięcia i rozerwanie, kiedy każda grupa usiłuje stale zmienić go na swoją korzyść. System ma cechy organizmu, ma także cykl życia, w którym jego cechy zmieniają się pod pewnymi względami i pozostają stabilne pod innymi względami. Życie w nim samym jest zazwyczaj niezależne, samowystarczalne, a dynamika jego rozwoju jest w dużym stopniu wewnętrzna. System-świat to coś co I. Wallerstein opisuje w kategorii gospodarki światowej, zintegrowanej raczej 
przez rynek niż centrum polityczne, w którym dwa i więcej regionów jest wzajemnie zależnych od siebie w odniesieniu do takich koniecznych rzeczy, jak jedzenie, paliwo i ochrona, a dwa i więcej państw politycznych konkuruje o dominację bez pojawienia się jednego pojedynczego centrum kiedykolwiek.

W swojej własnej pierwszej definicji z 1974 r. I. Wallerstein powiedział, że system-świat jest wielokulturowym, terytorialnym podziałem pracy, w którym produkcja i wymiana podstawowych dóbr i surowców jest konieczna dla życia codziennego jego mieszkańców. Ten podział pracy odnosi się do sił i relacji produkcji światowej gospodarki jako całości i prowadzi do istnienia dwóch wzajemnie zależnych regionów: centrum i peryferii. Są one geograficznie i kulturowo różne, jeden koncentruje się na intensyfikacji pracy, a inny na intensywnej kapitałowo produkcji. Relacje centrum - peryferia są strukturalne. Państwa w półperyferiach (semiperyferiach) działają jako strefa buforowa między centrum a peryferią, mają mieszankę aktywności i instytucji, które w nich istnieją.

Wśród najważniejszych struktur bieżącego systemu-świata jest hierarchia władzy między centrum i peryferią, w której potężne i zamożne centrum dominuje i eksploatuje słabą i biedną peryferyjną społeczność. Technologia jest centralnym czynnikiem, który pozycjonuje region albo w centrum, albo w peryferii. Zaawansowane lub rozwinięte kraje są w centrum, a mniej rozwinięte są na peryferii. Kraje peryferyjne są strukturalnie ograniczone do doświadczania takiego rodzaju rozwoju, który powiela ich poddańczy status. Zróżnicowana siła wielu państw w obrębie systemu jest istotna, aby utrzymać system jako całość, ponieważ silne państwa zwiększają zróżnicowany napływ nadwyżek do strefy centralnej. Jest to coś, co Wallerstein określał jako nierówna wymiana, systematyczny przekaz nadwyżek z półperyferyjnych (semiperyferyjnych) sektorów w peryferiach do wysoce technologicznego i industrialnego centrum. Prowadzi to do procesu akumulacji kapitału na globalną skalę i z konieczności obejmuje przywłaszczenie i transformację peryferyjnych nadwyżek.

Po politycznej stronie systemów-światów kilka pojęć wydaje się zasygnalizowanych. Dla I. Wallersteina państwa narodowe są zmiennymi elementami w obrębie systemu. Państwa są używane przez siły klasowe, aby śledzić ich interesy, w przypadku krajów w centrum. Imperializm odnosi się do dominacji nad słabymi peryferyjnymi regionami państw z centrum. Hegemonia odnosi się do utrzymania równowagi państwowej siły i narzucenia wolnego handlu, gdy tylko daje im to korzyści. Jednak hegemonia jest czasowa z powodu walki klas i dyfuzji korzyści technicznych. W końcu zachodzi też globalna walka klas.

Obecny system-świat jest charakteryzowany przez regularne cykliczne rytmy, które dostarczają podstawy do periodyzacji nowożytnej historii przez I. Wallersteina. Po naszym bieżącym stadium Wallerstein przewidział pojawienie się socjalistycznego światowego rządu, który jest jedyną alternatywą systemu-świata mogącą utrzymać na wysokim poziomie produktywność i zmianę dystrybucji przez zinte- 
growanie poziomów politycznego i ekonomicznego podejmowania decyzji. W dzisiejszych czasach, mniej więcej od końca XIX w., nowoczesny system-świat, jako kapitalistyczna gospodarka-świat, stanowi, za sprawą ekspansji wcześniej związanej z podbojami kolonialnymi, a współcześnie opartej na zasadzie tzw. wolnego handlu, prawdziwie globalny czy też ogólnoświatowy system gospodarczy. Jednak tym, co w tej ,światowości najważniejsze, nie jest zasięg geograficzno-polityczny, ale integralność powiązań pomiędzy centralnymi i peryferyjnymi procesami gospodarczymi oraz zależność obszarów geograficzno-politycznych, na których przeważają procesy drugiego rodzaju, od obszarów, w których ulokowane są przede wszystkim procesy o wysokim stopniu monopolizacji i zyskowności. System-świat, imperium-świat, gospodarka-świat zatem to pojęcia mające wymiar przede wszystkim jakościowy, a nie ilościowy" (Starnawski, Wielgosz 2007).

Kapitalistyczna gospodarka-świat odpowiada konkretnej rzeczywistości historycznej. Kapitalistyczna gospodarka-świat to obejmująca rozległe terytorium i względnie trwała, choć posiadająca znaczną dynamikę struktura wewnętrzna. Główne cechy systemu, który wyłonił się najprawdopodobniej w XVI w. i w którym współcześnie żyjemy, to po pierwsze nieustanna akumulacja kapitału jako siła napędowa systemu. Po drugie - osiowy podział pracy, w którym istnieją napięcia między centrum i peryferiami związane z mającą przestrzenny charakter nierówną wymianą. Po trzecie - występowanie obszarów półperyferyjnych (semiperyferii). Po czwarte duże i wciąż utrzymujące się znaczenie pracy nienajemnej obok pracy najemnej. Po piąte - pokrywanie się granic kapitalistycznej gospodarki-świata na kolejne obszary. Początkowo ścisłe centrum stanowiły północno-zachodnie obszary Europy, półperyferie to były kraje takie jak Hiszpania, zaś peryferie to tereny Europy Wschodniej, w tym Polski, jednak bez Rosji, która długo pozostawała samowystarczalnym obszarem zewnętrznym. Po szóste - istniały w tym systemie-świecie państwa hegemoniczne. Po siódme - państwa, grupy etniczne, gospodarstwa domowe były społecznie konstruowane. Po ósme - fundamentalne znaczenie miał rasizm i seksizm jako organizująca zasada tego systemu. Po dziewiąte - pojawiały się ruchy antysystemowe, które równolegle podkopywały i wzmacniały system. Po dziesiąte - występowały zarówno rytmy cykliczne, jak i trendy sekularne, które ukazywały wewnętrzne sprzeczności systemu i odpowiadały za kryzys systemowy, w którym się obecnie znajdujemy (Starnawski, Wielgosz 2007).

\section{RECEPCJA TEORII SYSTEMU-ŚWIATA W ARCHEOLOGII}

Zazwyczaj zaznacza się początek aplikacji teorii systemu-świata w archeologii od artykułu Michaela Rowlandsa i Jonathana Friedmana (1977). Według Halla i Chase-Dunna (1993) początkiem jednak jest referat konferencyjny R.A. Pailesa i J.W. Whitecottona z 1975 r. opublikowany w 1979 r. Artykuł J. Friedmana 
i M. Rowlandsa (1977) ukazał się zaraz po publikacji pierwotnych sformułowań Immanuela Wallersteina z 1974 r. Chociaż Friedman i Rowlands nie odnoszą się bezpośrednio do jego sformułowań, byli przypuszczalnie ich świadomi, ponieważ kilka elementów ich artykułu sugeruje pojęcia, które współcześnie są znane pod pojęciem modelu centrum-peryferii, w tym między innymi chodzi o koncentrację na centrum w wielu przypadkach sytuacji archeologicznych, nacisk na ruch surowców i luksusowych przedmiotów, związek między centrami i półperyferiami oraz mowa o plemiennych peryferiach specjalizujących się w dostarczaniu lokalnych produktów do dominującego centrum za tytuły i dobra z tych centrów.

Mniej więcej w tym samym czasie Philip Kohl (1987) opublikował artykuł w Current Anthropology dotyczący handlu w południowo-zachodniej Azji w trzecim tysiącleciu p.n.e., w którym powoływał się na książkę Immanuela Wallersteina z 1974 r.

W obrębie Europy pierwszym wydarzeniem, które przyciągnęło uwagę do teorii była konferencja w Aarhus zatytułowana: „Relacje pomiędzy Bliskim Wschodem a światem Śródziemnomorskim i Europą od trzeciego do pierwszego tysiąclecia p.n.e.”, zorganizowana przez Kristiana Kristiansena i Michaela Rowlandsa oraz z Morgensem Trolle Larsenem. Szerokie spektrum archeologów, włączając w to egiptologów i asyriologów, obecnych było na konferencji, większość z obecnych była zainteresowana relacjami handlowymi w przeszłości w różnych jej formach. $\mathrm{Na}$ tym spotkaniu wielu z badaczy po raz pierwszy zetknęło się z teorią systemówświatów. Wkrótce teoria ta stała się częścią teorii archeologicznej. Obrady i referaty $\mathrm{z}$ konferencji w Aarhus zostały następnie opublikowane w tomie Centre and Periphery In the Ancient World w 1987 r. pod redakcją M. Rowlandsa, M. Larsena i K. Kristiansena. Tylko zwolennicy teorii systemów-światów zostali zaproszeni do publikacji artykułów w tym tomie. Teoria systemów-światów została zaaplikowana do pradziejów Bliskiego Wschodu i Europy, a niektóre referaty rozciągnęły tę aplikację na późną epokę żelaza i okres wpływów rzymskich.

W 1985 r. podobna konferencja zorganizowana przez Petera Schauera odbyła się w Mainz pod tytułem „Ägäische Einflüsse in der europäischen Bronzezeit”, materiały pokonferencyjne opublikowano w 1990 r. w Mainz. Peter Schauer opublikował serię artykułów na ten temat w latach osiemdzisiątych XX w., które rozciągnęły się na poglądy, jakie zaprezentował w Aarhus. Konferencja w Mainz, jak ukazują to opublikowane artykuły, prezentowała raczej tradycyjny ogląd na relacje międzykulturowe. W dyskusji pojęcie system-świat raczej nie padało i nie pada w publikacji.

W 1986 r. na inauguracyjnym World Archaeological Congress zaproponowano sesję, która otrzymała tytuł „Comparative Studies In the Development of Complex Societies". Referaty i artykuły z tej sesji opublikowano w 1989 r. pod postacią książki zatytułowanej: Centre and Periphery: Comparative Studies In Archaeology pod redakcją T. Championa. Chociaż wielu autorów z ostrożnością podchodziło do teorii systemów-światów, jedynie wprowadzenie T. Championa ukazuje przegląd 
badawczy archeologii. Referaty pozostałych uczestników konferencji dotyczyły różnych części świata, a większość z nich omawiała okresy późniejsze niż pradzieje, włączając w to okres wpływów rzymskich i średniowiecze.

W 1992 r. w Bristolu miała miejsce konferencja pod auspicjami The Prehistoric Society zatytułowana „Trade and Exchange In Prehistoric Europe”. W 1993 r. wydano referaty konferencyjne pod redakcją C. Scare i F. Healy. Na konferencji tej Andrew Gunder Frank miał wystąpienie, w trakcie którego wywiązała się dyskusja z Andrew Sherrattem. Obaj opublikowali ważne artykuły. Andrew Gunder Frank (1993) w Current Anthropology opisał teorię systemów-światów w odniesieniu do Bliskiego Wschodu w starożytności, a potem na ten sam temat wydał książkę przy współautorstwie Barrego Gillsa (Frank, Gills 1993), w której podejście to było rozwinięte. Andrew Sherratt (1995) swoją własną wersję teorii systemów-światów zaaplikował do Europy w epoce brązu. Następnie ukazała się ona jako publikacja w Journal of European Archaeology, jak również w tomie po konferencji w Bristolu.

Inni autorzy rozwijali swoje koncepcje prezentowane na wspomnianych konferencjach. Kolejny artykuł po konferencji w Aarhus opublikował obecny na niej Philip Kohl (1987). W 1980 r. zdecydował się na krytykę teorii systemów-światów, ale krytykując model, po raz pierwszy zwrócił uwagę na takie elementy teorii I. Wallersteina, które wymagały dopracowania i następnie zostały przez niego, w odpowiedzi na krytykę, z sukcesem rozwinięte w archeologii. Kohl w rzeczywistości dostrzegł dynamikę systemu-świata obejmującego takie regiony, jak Mezopotamia i inne centralne obszary, włączając w to Azję Centralną. Jak trafnie zauważył, dostrzegał także istnienie wielu centrów, co wskazywało na podstawową sprzeczność między teorią I. Wallersteina a systemem-światem epoki brązu. Jak pisał Philip Kohl(1987): „świat epoki brązu składał się z nakładających się systemów, które stale się zmieniały i modyfikowały swoje granice".

Przyjął, że jeżeli system-świat Wallersteina nie pasował do starożytności, to zadaniem archeologów było wykryć te różnice i zrozumieć dlaczego zaistniały.

Prace Andre Gunder Franka zgadzały się z pracami wielu archeologów, nie było ich krytyki, chociaż widać było, że Frank opiera się na źródłach pośrednich w odniesieniu do archeologii okresów, jakie omawiał. Krytyka Michaela Dietlera (1998) i Gil Steina (1999) jest chyba najbardziej znana, chociaż wielu autorów było sceptycznych co do osiągnięć Franka.

Od lat dziewięćdziesiątych XX w. zaczyna być publikowana reakcja socjologów na teorię I. Wallersteina. Najważniejsze publikacje to prace Christophera Chase-Dunna i Thomasa Halla, dwóch autorów, którzy stali się zwolennikami teorii systemów-światów. W 1995 r. z inicjatywy Christophera Chase-Dunna powstał Journal of World-Systems Reseach, w którym publikowało również kilku archeologów.

Od tego czasu wydaje się, że istnieje milczące założenie, że teoria systemów-światów jest użytecznym modelem do aplikacji. Aplikacje uczyniono praktycznie dla każdego okresu i obszaru. W kontekście Europy pradziejowej, w szczególności 
dla epoki brązu, najliczniejsze są prace Kristiana Kristiansena (1994) i są one najczęściej cytowane. Entuzjastycznym adwokatem teorii systemów-światów stał się także Nick Kardulias (1999). Ostatnie numery JWSR obejmują liczne artykuły z zakresu archeologii, a jeden z nich napisał politolog D. Wilkinson (2004). Ta wymiana poglądów między badaczami pracującymi w różnych dyscyplinach jest szczególnie ważna.

Oczywiście nie tylko archeolodzy interesowali się teorią systemów-światów. Niektórzy historycy także wydają się dostrzegać cykle w rozwoju systemów kulturowych na badanych przez siebie obszarach. Na przykład T.J. Barfield w 1989 r. odnosi się do cykli władzy w relacjach między stepowymi nomadami Azji centralnej a królestwem chińskim. Abu-Lughod (2012) rozciągnęła zasięg teorii systemówświatów do okresu XII i XIII w. w świecie euroazjatyckim.

Zdaniem Anthony’ego Hardinga (2013) warto rozróżniać teorię systemówświatów i teorię zależności („dependency theory”). Teoria zależności oparta jest na zasadach, że istnieją centralne jednostki państwowe czy państwa peryferyjne oraz że surowce przepływają od tych ostatnich do tych pierwszych, wzbogacając je kosztem peryferii. Teoria zależności zajmuje się nierozwiniętymi narodami w świecie współczesnym oraz naturą, która powoduje niedorozwój. Podczas gdy to w ogólnych zarysach odnosi się do teorii systemów-światów. Teoria systemów-światów obejmuje pewne aspekty, które nie są obecne w teorii zależności - w szczególności wzajemnie zależną naturę powiązań między dwoma częściami i cykliczną naturą systemu. Teoria zależności tylko sugeruje, że jeden obszar zależał od drugiego, zaś teoria systemów-światów mówi, że oba obszary były nierozerwalnie połączone zarówno w sposób materialny, jak i społeczno-kulturowy.

Ostatnie artykuły Nicka Karduliasa prezentują w sposób jawny i prosty podstawowe założenia odnoście epoki brązu: społeczeństwa dzisiaj i w epoce brązu nie istniały w stanie izolacji, trendy społeczne mają postać cykli czy wzorów. Nick Kardulias jest zwolennikiem analizy systemów-światów, jest to ogólne, generalizujące pojęcie, które zmusza nas do dostrzegania całego lasu istniejących zewnętrznych powiązań, w których indywidualne archeologiczne stanowiska są zakorzenione. Analiza systemów-światów dostarcza pojęciowego schematu, aby zrozumieć funkcje systemu. Obraca się ona wokół pojęć centrum i peryferii, jakkolwiek je zdefiniować, obejmuje ona również pojęcie świata, który jednak nie jest globalną całością, lecz czymś, co odnosi się do będących we wzajemnej interakcji społeczno-politycznych jednostek. Główną cechą analizy systemów-światów jest to, że podkreślają one interakcję jako centralną dla kulturowej formacji i zmiany. W tym samym czasie możliwa jest modyfikacja podstawowych pojęć, po to, aby wzrosła ich użyteczność, na przykład przez stworzenie pojęcia ,negocjowanej peryferii”, w której ludzie żyjący na peryferii czy marginesie mogą zdefiniować naturę i zakres interakcji z centrum, przynajmniej do pewnego stopnia. Perspektywa systemów-światów umożliwia rozważenie szerszej perspektywy niż tylko pojedyncza kultura na wybranym obszarze, 
ponieważ podstawową jednostką historycznego rozwoju nie są pojedyncze społeczeństwa, lecz całe międzyspołeczne kontakty, w obrębie których takie indywidualne społeczeństwa istnieją.

To pisma Andre Gunder Franka promowały pogląd w swojej najbardziej ekstremalnej formie, że istniał system-świat mający 5 tysięcy lat, który rozciągał się w nieprzerwalnej kontynuacji historycznej między centralną cywilizacją/systememświatem epoki brązu i naszym współczesnym kapitalistycznym systemem-światem, który był rzekomo tym samym systemem, mimo licznych modyfikacji, które przeszedł w czasie tych wszystkich lat. Frank wydaje się wierzyć, że jakakolwiek sytuacja, w której można zademonstrować kontakty handlowe i tendencję do wzrostu i upadku, kwalifikuje się do dopuszczenia jej do kategorii system-świat.

Inni obserwatorzy, w tym Andrew Sherratt, zaadaptowali bardziej zniuansowane podejście do tego problemu. Postawił on celne pytanie, gdzie była luka technologiczna, taka jak między zaawansowanymi technologiami wschodniego basenu Morza Śródziemnego w epoce brązu a tymi w kontynentalnej Europie i dlaczego zaszła asymetria relacji między tymi dwoma regionami, czy to było to samo co system-świat? Przez zaadaptowanie pojęć i uwolnienie ich z konotacji wymiany, które stosowane są we wczesnym kapitalistycznym świecie, można zdaniem Sherratta stosować model ten do systemów centrum-peryferia na dużą skalę, zaczynających się na Bliskim Wschodzie i w Egipcie. W istocie chodzi o obszar zurbanizowany $\mathrm{i}$ ich tereny dostawy. Sherratt jest krytyczny w stosunku do pojęcia peryferii, woląc zamiast tego pojęcie marginesu, jako obszaru poza peryferią, i postrzegając lepiej pojęcie jądra, rdzenia i marginesu bardziej niż centrum-peryferie. Stają się one pojęciami opisu z niewiele głębszym znaczeniem. Andrew Sherratt dostrzegał wzrost handlu marginalnego w epoce brązu, dostrzegał w szczególności lukę technologiczną między rdzeniem a marginesem, i uważał, że ucieczka produktów centralnych do marginesu była rozciągniętym w czasie zjawiskiem, a nie strukturalną współzależnością między bardziej zaawansowanymi cywilizacjami i mniej zaawansowanymi kulturami. Sherratt był w stanie rozwinąć swoje pojęcie systemu centrum/rdzenia-peryferii/marginesu, $\mathrm{z}$ nowymi marginesami tworzącymi nowe rdzenie, ponieważ same składały się z centrum i peryferii. Niemniej w istocie Sherratt zaakceptował ideę, że katalityczne kontakty były odpowiedzialne za mobilizację potencjałów $\mathrm{w}$ nowych systemach produkcji. W szczególności użycie brązu jako środka wymiany było instrumentalne, zarówno pozwalając na formowanie się małych struktur centrum-peryferii w niektórych lokalizacjach w obrębie marginesu, jak i wpływając na wzór powiązań, które wyrastały między nimi. Jego definicja systemu-świata w drugim jego referacie z 1993 r. sugerowała, że zaakceptował on istnienie takiego zjawiska. Jego koncepcja była zasadniczo różna od koncepcji Franka i Gillsa.

Kristian Kristiansen rozwinął (1998) swoje ujęcie systemu-świata epoki brązu już w latach osiemdziesiątych XX w. Usiłował postrzegać skandynawską epokę 
brązu przez pryzmat rytuału, władzy i prestiżu. Przyjął, że zachodziły dwa rodzaje relacji centrum-peryferii: regionalne i lokalne. Do 1994 r. rozwinął pełniejszy model, gdzie zaprezentował trzy strukturalne warianty modelu systemu-świata w osadnictwie i społeczeństwie epoki brązu i żelaza: osiadłe centra produkcji i redystrybucji, społeczeństwa wojowników i duże chłopskie społeczności. Co ważne dla systemu-świata, zaobserwował cykliczne wzory w relacjach osadniczych i międzyspołecznych. Na zaobserwowane przez Kristiansena cykle mógł mieć wpływ klimat. Obok produkcji żywności równie ważne było dla niego tworzenie i użycie bogactwa, jak i rola wymiany. Tak więc zidentyfikował trzy wzory relacji centrumperyferii i zasugerował regularną zmianę zależności i dominacji w czasie. Książka Kristiansena z 1998 r. Europe before history w dużej mierze jest oparta na inkorporacji modelu systemu-świata, chociaż zasadniczo rozwija idee z artykułu z 1994 r. Kristiansen postrzegał Europę w późnej epoce brązu jako pokrytą serią regionalnych tradycji, tworzących regionalny system. Regionalne tradycje miały, według niego, pewne wspólne dobra prestiżowe i przez wymianę elit zmieniały się wzory międzyregionalnej (ponadnarodowej) sieci wymiany trzymającej ten system razem. Na poparcie tych idei rozwinął on serię studiów przypadków. Poglądy Kristiansena na system-świat wydają się być rozpowszechnione. Zdaniem Kristiansena (2011) system-świat epoki brązu jest heurystycznym narzędziem, które pozwala nam myśleć i prześledzić siły historii $\mathrm{w}$ ich pełnym zasięgu, pojęcie systemu-świata epoki brązu staje się „granicą interpretatywną, która wyzywa konwencjonalną mądrość”. W tym sformułowaniu inkorporacja umiarkowanej Eurazji do świata epoki brązu obejmuje ekspansję mobilnych, pasterskich społeczeństw ze stepów, nowe postrzeganie rodziny, gender i własności prywatnej, pojawienie się męskiego wojownika/wodza, a także rozprzestrzenienie się języka indoeuropejskiego, rozprzestrzenienie się rydwanu wojennego około 2000 r. p.n.e. i zasięg innych instytucjonalnych i rytualnych elementów, które reprezentują sferę ideologiczną w ludzkim społecznym życiu.

Wielu innych autorów aplikowało teorię systemów-światów, chociaż w dużo mniej dogmatycznej formie. Berg na przykład bierze za pewnik, że strefa egejska w epoce brązu była domem różnych systemów-światów. Bierze pod uwagę to, że starożytne społeczeństwa nie były jakościowo, lecz tylko ilościowo różne od współczesnych kapitalistycznych społeczeństw. I. Berg w 1999 r. zaaplikowała teorię systemów-światów do południowych wysp egejskich w środkowym i późnym brązie. Omawia różne sieci handlowe, które są wyraźnie obecne w południowej Egei. Konkluduje to stwierdzeniem: „Jak to staje się oczywiste z powyższej prezentacji, południowoegejski system składał się z centrum i półperyferii. Nie było peryferii w tym regionie". To twierdzenie jest typowym przykładem postepowania zaadoptowanym przez wielu zwolenników teorii systemów-światów. Mechanicznie identyfikują sieci handlowe, umieszczają je w obrębie schematu teorii systemów-światów, lecz ignorują potrzebę zademonstrowania istnienia systemu takiego jak system-świat w działaniu. 
Anthony Harding uważa, że archeolodzy po prostu nie mają wystarczających informacji, aby udowodnić, że taki system istniał, nawet w obrębie egejskiej epoki brązu. Podobny krytycyzm stosuje Dietler (1998) i Knappett (2011).

Ostatni artykuł Warburtona z 2011 r. ukazuje wycofywanie się Warburtona z poglądu, że system-świat istniał w epoce brązu. Autora głównie interesują założenia na temat towarów, jakie były w handlu (bursztyn, lapis lazuli, nefryt). W obecnej archeologii nie istnieją dowody na udokumentowanie tezy, że w epoce brązu Europa była peryferią Egei, jak twierdziła Berg.

Dzisiaj przeważa pogląd, że wiele obszarów było w pradziejach częścią większego systemu-świata. Niemniej nie wszyscy obserwatorzy takiego stanu są przekonani o użyteczności teorii systemu-świata. Warto przywołać w tym miejscu krytykę Steina z 2002 r. oraz Knappetta z 2011 r. Knappett na przykład wskazuje, że teoria systemu-świata jest teorią dedukcyjną, od góry do dołu, koncentrującą się na instytucjach i ignorującą poziom mikro, typ interakcji wzajemnej, osoba do osoby. Wg niego zaprzecza ona roli kultury materialnej jako aktywnej i aktywizującej znaczenia, z instytucjami będącymi zmaterializowanymi w kulturze materialnej. Jest ważna w sposobie, w jaki przedstawia przestrzeń, szczególnie to, co jest centrumperyferią czy też „kulturami odbiorczymi”. Zdaniem Knappetta peryferia są tylko biernymi odbiorcami z centrum. Teoria systemów-światów nic nie mówi o gender i tożsamości na poziomie jednostki i grupy, chociaż ważne jest, że spostrzegł to i rozwinął z sukcesem Nick Kardulias (2007), jak również inni autorzy po nim. Michael Dietler (1998) krytykuje teorię systemów-światów jako koncentrującą się tylko na elementach ekonomicznych, przez to czyniącą, wg niego, peryferię tylko pasywnym obiektem manipulowanym przez zewnętrzne siły. Przekonanie to prawdopodobnie wyrasta $\mathrm{z}$ tego, że teoria systemów-światów powstała na gruncie marksistowskim, w którym eksploatacyjna natura dalekosiężnych relacji została podkreślona.

W chwili obecnej jest dobry czas, aby ponownie rozważyć użyteczność, wiarygodność modelu systemu-świata, chociażby tylko w odniesieniu do epoki, dla której jest szeroko stosowana w archeologii pradziejowej, a mianowicie do epoki brązu.

\section{SYSTEM-ŚWIAT EPOKI BRĄZU}

Andrew Sherrat, brytyjski, nieżyjący już, archeolog, zaproponował w $1993 \mathrm{r}$. ujęcie metodologiczne przedstawiające rozwój społeczeństw epoki brązu postrzeganych z perspektywy zmian form wymiany dóbr. Propozycja ta, nawiązująca bezpośrednio do teorii systemów-światów, jest znacząco inna niż ujęcia przemian społecznych tworzone przez archeologów tradycyjnych (kulturowo-historycznych). $\mathrm{Z}$ tego też powodu wywołała wiele kontrowersji. Sądzę jednak, że w tym miejscu warto ją zaprezentować jako alternatywę wobec ciągle dominujących w nauce ujęć kulturowo-historycznych. 
Podstawowym założeniem teoretycznym przyjętym przez twórcę tego modelu wymiany w epoce brązu jest podział ówczesnej Europy na odrębne strefy, nazwane centrum - peryferią - marginesem, co wynika z inspiracji teorią systemów-światów Immanuela Wallersteina. Koncepcja wymiany przyjęta przez Andrew Sherratta, inspirowana etnologicznymi koncepcjami wymiany, odpowiada najbardziej interpretacji potlaczu. Najogólniej opisując, w systemie wymiany zwanym potlaczem członek określonej grupy społecznej kształtował i wyrażał swój status społeczny przez publiczne rozdawnictwo dóbr, które przyjmowało postać darów w trakcie wydawanych uczt. Na najniższym, najbardziej podstawowym poziomie organizacji społecznej potlacz był mechanizmem redystrybucji dóbr, dzięki któremu wyprodukowane i zgromadzone nadwyżki były mniej więcej równo rozdzielane wśród członków społeczności. Jednocześnie podczas uczt panowała atmosfera rywalizacji, bo potlacz był środkiem w konkurencyjnej walce o status społeczny. Tego rodzaju uczty najprawdopodobniej nieobce były starożytnemu światu greckiemu. O tym świadczyć może przykład Posejdoniosa i nawiązujących do niego autorów greckich, którzy pisali o ucztach, podczas których wojownicy najpierw rozdawali zgromadzone przez siebie bogactwo między krewnych i znajomych, a następnie godzili się na zadanie sobie śmierci.

Ze względu na rozwój produkcji metalurgicznej i różnych form wymiany Andrew Sherratt podzielił epokę brązu na kilka faz nieodpowiadających klasycznej chronologii epoki brązu. Zaproponowana przez niego chronologia rozpoczyna się wraz z wczesną epoką brązu w basenie Morza Śródziemnego, a więc obejmuje także okres eneolitu w Europie Centralnej. Faza pierwsza to okres od 3000 r. p.n.e. do 2500 r. p.n.e., w Europie Centralnej to jeszcze eneolit, zwany też późnym neolitem. Faza druga przypada na okres od 2500 r. p.n.e. do 1800 r. p.n.e. Faza trzecia to lata od około 1800 r. p.n.e. do 1600 r. p.n.e. Faza czwarta to okres od 1600 r. p.n.e. do 1300 r. p.n.e., i ostatnia faza, piąta, obejmuje czas od 1300 r. p.n.e. do 700 r. p.n.e.

$\mathrm{W}$ pierwszej fazie centrum stanowił, tak jak w okresie neolitu, obszar bliskowschodni, ze szczególnym zaakcentowaniem Anatolii i wschodniej części basenu Morza Śródziemnego. Zdaniem Andrew Sherratta na tym obszarze po wprowadzeniu rolnictwa nie został zaprzestany proces innowacji. To tam najwcześniej pojawiło się radło, wykorzystanie siły pociągowej zwierząt, a zarazem transport kołowy, mleczarstwo, tkactwo wełny, czyli zjawiska, które Sherratt określił jako „drugą rewolucję neolityczną". Zmiany technik wytwarzania podstawowych produktów materialnych przyczyniły się do zmian w stylu życia: zmieniła się dieta, ubiór (pojawiły się ubrania wełniane), wyposażenie domostw (coraz bardziej ozdobna ceramika, także stopniowo naczynia metalowe), środki transportu, uzbrojenie. W społeczeństwie, najprawdopodobniej jeszcze $\mathrm{w}$ eneolicie, wykształciły się dwie grupy odbiorców dóbr: elity zainteresowane dobrami luksusowymi oraz reszta społeczeństwa, która była odbiorcą towarów produkowanych masowo. 
W produkcji towarów na masową skalę szukano możliwości ulepszania technologii wytwórczych tak, aby produkować więcej, przy jak najmniejszym nakładzie pracy i materiału. Przykładem takiej technologii jest toczenie ceramiki. Wprowadzenie tego wynalazku pozwoliło wyprodukować więcej naczyń przez jedną osobę z mniejszej ilości gliny i w krótszym czasie. Produkcja towarów luksusowych opierała się na całkowicie innych zasadach. Wytworzenie towarów luksusowych było bardzo czasochłonne i pochłaniało dużą ilość kapitału, z tego względu produkcja ta była, najprawdopodobniej od samego początku jej istnienia, kontrolowana przez powstające centra administracyjne i ograniczona była do małej grupy społecznej, czyli ścisłej elity (osób będących u władzy). Równocześnie z produkcją dóbr luksusowych rozwijała się imitacja tych dóbr, w wykonaniu tańszym, a co za tym idzie w gorszej jakości materiale. Naśladownictwa dóbr luksusowych znajdowały swych odbiorców w innych niż elitarne warstwach społecznych. Na przykład wyroby złote, dostępne tylko dla elity, kopiowane były w brązie, a na obszarach centralnej Europy kształt pierwszych wyrobów brązowych naśladowano w krzemieniu i kamieniu. Naśladownictwo było często uproszczone pod względem technologicznym. Na południu Europy duże znaczenie miało złoto i srebro, w centralnej i północnej Europe - brąz. W ten sposób przez naśladowanie rozprzestrzenił się z centrum styl życia charakteryzujący początkowo tylko elity, a związany ze sposobami odżywiania się, ubiorem, wystrojem wnętrz, zachowaniem się.

Andrew Sherratt przyjął, że pojawienie się dóbr luksusowych na obszarach peryferyjnych początkowo spowodowane było czystą fascynacją osiągnięciami technicznymi, na przykład z Bliskiego Wschodu i Anatolii na obszar południowowschodniej, a następnie centralnej Europy. W ten sposób zapożyczono transport kołowy (proste wozy), konia, elementy oporządzenia końskiego, produkcję wełny i wełniane ubrania, metalurgię brązu i pierwsze wyroby brązowe, radło, metalowe naczynia, najprawdopodobniej także ich zawartość, czyli napoje, jakie były w nich przechowywane i konsumowane.

Pojawiające się nieznane wcześniej na obszarze europejskim produkty i nowinki techniczne miały na początku tylko znaczenie prestiżowe, funkcjonowały bardziej w świecie ideologii niż praktyki, jako wyznacznik wyższego statusu społecznego. Były postrzegane jako luksusowe. Odkrycie ich praktycznego znaczenia nastąpiło dopiero wraz z upływem czasu, najprawdopodobniej w chwili, gdy ich posiadacze uzmysłowili sobie korzyści wynikające nie tylko z ich posiadania, ale i z ich zastosowania. Innowacje adaptowano selektywnie w chwili, gdy olbrzymie połacie Europy dostosowywały się jeszcze do rolnictwa. Praktyczne wykorzystanie nowinek przyczyniło się do dalszych przemian gospodarki w południowo-wschodniej i centralnej Europie, temu procesowi miałyby odpowiadać kultury archeologiczne późnego eneolitu. Przenikanie nowinek technicznych może być zatem postrzegane w kontekście rywalizacji społecznej, głównym motywem ich posiadania było pożądanie określonego produktu jako wyznacznika pozycji społecznej, a dopiero w dalszej kolejności chodziło o jego znaczenie praktyczne. Nowe produkty musiały być zatem ograniczone do małej 
grupy lokalnych konsumentów (do elity peryferyjnych społeczności). W Europie zachodniej proces przejmowania nowinek technologicznych Andrew Sherratt utożsamił z rozprzestrzenianiem się kultury pucharów dzwonowatych.

W drugiej fazie wyróżnionej przez Andrew Sherratta standardowym środkiem wymiany stał się brąz, ze względu na swoją łatwą do transportu formę (placki stopu lub blacha brązowa). W miejscu docelowym osoby zaznajomione z metalurgią brązu mogły nadać surowcowi pożądany lokalnie kształt. Kultury archeologiczne z lokalnie produkowanymi wyrobami z brązu pojawiły się najpierw wzdłuż Dunaju (kultura Otomani-Fützesabony, kultura unietycka), co zdaniem badacza jest dowodem na związek produkcji metalurgicznej ze szlakami wymiany.

Pojawienie się brązu w starszej części epoki brązu nie przyczyniło się do innych zmian w zastanej po eneolicie na obszarach naddunajskich kulturze materialnej, na przykład w wytwórczości garncarskiej. Wyroby brązowe znane są z osad, a także, przede wszystkim, z cmentarzysk, co pośrednio może świadczyć o roli brązu tylko w życiu ceremonialnym danych społeczności. $Z$ obszarów naddunajskich wyroby brązowe napływały do centralnej Europy na przykład na obszary, na których archeolodzy wyróżnili kultury archeologiczne związane z kulturą unietycką.

Pojawiające się wyroby brązowe o wartości przede wszystkim prestiżowej stały się katalizatorem zmian społecznych. Pojawiło się lokalne naśladownictwo, co spowodowało wzrost wydobycia miedzi i cyny, powstanie nowych ośrodków metalurgicznych, na przykład ośrodka we wschodnich Alpach, a także zwiększenia się asortymentu wyrobów metalowych.

Z czasem wyroby brązowe stawały się w społeczeństwie coraz bardziej powszechne. Zjawisko to Andrew Sherratt określił współczesnym mianem „inflacji” wartości wyrobów brązowych. Elity kontrolujące produkcję metalurgiczną, aby uniknąc przenikania wyrobów brązowych, będących nadal wyznacznikiem pozycji społecznej, do warstw niższych, zaczęły eliminować ich nadmiar z obiegu. Dzięki temu, że je zakopano, przetrwały do naszych czasów w postaci „skarbów” kultury unietyckiej. Największa liczba skarbów znana jest z najbliższego otoczenia ówczesnego ośrodka metalurgicznego w południowych Niemczech. W odkrytych skarbach mamy do czynienia tylko z jednym typem przedmiotu brązowego wyprodukowanego w dużej ilości.

Trzecią fazę rozwoju wymiany Andrew Sherratt utożsamił ze schyłkiem archeologicznych kultur Otomani-Füzesabony oraz unietyckiej. Jego zdaniem był to okres maksymalnego rozwoju szlaków wymiany dalekosiężnej, które miałyby przeciąć całą Europę, sięgając od obszarów anatolijskich, nawet bliskowschodnich i kaukaskich, przez Kotlinę Karpacką na południe, po północną Italię, na zachód i północ aż po Skandynawię. Tę fazę można prześledzić analizując jedynie dystrybucję wyrobów brązowych, także ceramicznych, bursztynowych w całej Europie.

W czwartej fazie, zdaniem Sherratta, na południu Europy możemy mówić już o urbanizacji. W skali europejskiej nastąpiło rozbicie produkcji metalurgicznej na wiele lokalnych ośrodków, zaś wymianę dalekosiężną zastąpiły łańcuchowe powiąza- 
nia między sąsiadującymi ze sobą obszarami. Tą drogą, w formie wymiany dwustronnej (najprawdopodobniej właśnie wymiany darów, być może przypominającej wspomniany na wstępie potlacz), transportowane były nadal wyroby brązowe, w zamian na przykład za bursztyn. Rozwój lokalnych ośrodków metalurgicznych, często opartych na importowanym surowcu (klasycznym przykładem jest metalurgia kultury nordyjskiej), przyniósł wzrost ilości oferowanego asortymentu towarów; archeologicznie to zjawisko jest prawdopodobnie uchwytne w większej liczbie znanych typów ozdób, szpil, fibul, bransolet, uzbrojenia itd. Na znaczeniu zyskały kontakty regionalne, na przykład wzdłuż wybrzeży morskich Morza Bałtyckiego czy Morza Tyrreńskiego.

W ostatniej fazie wyróżnionej przez Andrew Sherratta we wschodniej części basenu Morza Śródziemnego wystąpił kryzys gospodarczy, który miał spowodować uwolnienie tajemnic produkcji metalurgicznej spod kontroli ośrodków południowych, a to z kolei zwiększyło intensywny przepływ innowacji technologicznych. Nowinki technologiczne były szybko absorbowane przez rozwijające się nadal w różnych częściach Europy ośrodki metalurgiczne. W rezultacie w europejskiej produkcji metalurgicznej ponownie powiększył się asortyment wyrobów brązowych, co można prześledzić, analizując inwentarz wyrobów brązowych znanych z obszaru kręgu kultur pól popielnicowych. Duża liczba produkowanych wytworów brązowych sprawiła, że powszechny stał się dostęp do wyrobów brązowych dla większości warstw społecznych. Wyroby brązowe przestały pełnić funkcję wyznacznika prestiżu społecznego, a stały się dobrem powszechnie wymienianym i użytkowanym. Była to jednocześnie faza intensyfikacji gospodarki rolniczej. Na znacznych obszarach europejskich pojawiły się duże ufortyfikowane osady ze śladami wytwórczości metalurgicznej i innego typu rzemiosł, będące także ważnymi punktami na szlakach wymiany, są to tzw. osady typu biskupińskiego. Wzrost roli społecznej rzemieślników ma odzwierciedlenie w typowych dla tej fazy grobach metalurgów brązu, w których występują między innymi tygle odlewnicze. Intensyfikacja wymiany oraz wzrost asortymentu wyrobów brązowych to kolejna ich ,inflacja” oraz kolejna próba jej przeciwdziałania, ponownie tworzone były skarby. Pod koniec tej fazy pojawiło się żelazo, ale wyroby żelazne początkowo nie miały większego znaczenia.

Model Andrew Sherratta oparty na analizach dystrybucji wyrobów brązowych jest próbą pogodzenia teorii $\mathrm{z}$ archeologiczną praktyką. Badacz ten, jako jeden z nielicznych archeologów, próbował dostrzec zachowania społeczne, a dokładniej zachowania ekonomiczne, za materialną warstwą artefaktów.

\section{KRYTYKA APLIKACJI TEORII SYSTEMÓW-ŚWIATÓW DO BADAŃ NAD EPOKĄ BRĄZU}

Naczelnym krytykiem modelu systemu-świata epoki brązu jest Anthony Harding (2013). Przyjmuje on również, że Europa w epoce brązu była ściśle powiązana ze sobą, lecz rozwija on własny model oparty na indukcji, czyli wnioskowaniu 
z dołu do góry, który ma tę tezę udowodnić. Jednocześnie Anthony Harding krytykuje wykorzystanie źródeł w modelu systemu-świata. Anthony Harding analizuje głównie epokę brązu, ponieważ uważa, że z tym okresem jest najściślej związany oraz dlatego, że wielu zwolenników teorii systemów-światów, którzy zajmują się właśnie tym okresem, ogranicza się tylko do starego świata, chociaż wie, że wielu zwolenników teoria ta ma także wśród badaczy Mezoameryki oraz wśród badaczy Bliskiego Wschodu w starożytności, dla którego to okresu istnieją już liczne źródła pisane. Źródła te dostarczają bezpośrednich dowodów na istnienie systemu handlu wiążącego różne miasta i państwa bliskowschodnie trzeciego i drugiego tysiąclecia p.n.e.

Usiłując zrozumieć naturę społecznej i politycznej organizacji w obrębie społeczeństw wczesnoeuropejskich, należy podnieść serię pytań o to, jak ich wewnętrzna organizacja rzutowała na świat zewnętrzny. Nawet w społeczeństwach o małej skali grupy ludzkie nie mogły istnieć w izolacji, ponieważ już chociażby utrzymanie wielkości grupy wymagało interakcji z grupami sąsiednimi, po to, aby zapewnić reprodukcyjny sukces. Gdy grupy stawały się większe, takie problemy nadal pozostawały, chociaż łatwiej było je zaspokoić. Kontakt ze światem zewnętrznym jest oczywisty na większości obszarów późnych pradziejów europejskich, ponieważ materiały i artefakty mogą być często pokazywane jako wydobywające się z obszarów innych niż te, na których zostały znalezione.

Wraz z upływem czasu kontakty te wydają się być ważniejsze i bardziej natężone. Podczas gdy w neolicie głównymi archeologicznie zachowanymi materiałami, które były wymieniane, był kamień (na siekierki i ostrza) oraz muszle (na ozdoby), to już w epoce brązu i epoce żelaza wymieniano całe serie materiałów. Najbardziej zauważalnymi były wymiany metali, ale także takich surowców, jak koral, bursztyn i szkło. Także w tych okresach (od trzeciego do pierwszego tysiąclecia p.n.e.) rozwinęły się wielkie pałacowe cywilizacje wschodniej części basenu Morza Śródziemnego, a później powstały protopaństwa i państwa centralnego śródziemnomorza. To doprowadziło do godnego uwagi zjawiska, a mianowicie do potrzeby dużej ilości surowca dla złożonych społeczeństw południa i wschodu Europy, przede wszystkim, lecz niewyłącznie, metali. Użycie tych metali na dużą skalę jest bardzo zauważalne w społeczeństwach, w których były one oznaką wysokiego prestiżu społecznego. Równolegle z tym importowano, jednak w mniejszym stopniu, także egzotyczne surowce, takie jak: bursztyn czy lapis lazuli czy nawet specjalne drewno hebanowe z Afryki.

Pierwszym zarzutem, jaki stawia Anthony Harding teorii systemów-światów, jest to, że zarówno przed aplikacją modelu do archeologii, jak i w trakcie minionych trzydziestu lat jej funkcjonowania $\mathrm{w}$ archeologii wielu badaczy niezwiązanych z modelem podkreślało istnienie licznych powiązań między poszczególnymi regionami Europy w epoce brązu i także poza nią w innych okresach.

W chwili obecnej nie można wątpić, że świat epoki brązu był wzajemnie powiązany. Już dawno temu badacze doszli do wniosku, że społeczeństwa europejskie 
świata epoki brązu były powiązane więzami ekonomicznymi (handlowymi), a także na pewnym poziomie przynajmniej przez czynniki społeczne i kulturowe. Jest to obszar badawczy, w którym częste były dyskusje dotyczące spraw społecznokulturowych. W tym kontekście wymienić można debaty Jana Bouzka (1994), Petera Schauera, Kristiana Kristiensena i Anthony'ego Hardinga (1984). Jednakże w debatach tych panowała zawsze zgoda co do założenia o istnieniu szlaku bursztynowego łączącego Bałtyk, południową Anglię, centralną Europę i Grecję. Według badaczy wzdłuż tego szlaku miał miejsce przepływ unikalnych, bursztynowych plakietek. Taki typ artefaktu mógł pochodzić tylko z jednego obszaru i mógł być rozpowszechniony na inne tereny, a nie niezależnie wynaleziony. Materiał do jego wyrobu pochodził znad Bałtyku.

Od lat osiemdzisiątych XX w., kiedy pojawiła się większość prac na ten temat, nastąpiło wiele odkryć, które potwierdzają ideę, że istniało wiele powiązań handlowych w Europie. Odkrycie łodzi wykonanej z pnia drewnianego w Dover w 1992 r. rzuciło nowe światło na pytanie o morskie podróże w epoce brązu. Zaczęto zastanawiać się, czy dzięki takim łódkom można było przepłynąć Kanał La Manche.

Ostatnio bardzo ciekawe studium handlu bursztynem zostało przygotowane przez Janusza Czebreszuka (2011). Ważność bursztynu w basenie Morza Śródziemnego została także doceniona przez włoskich badaczy Radina i Recchia w 2010 r. Stuart Needham (2009) powołał nawet do życia termin „Maritory”, czyli obszar morski, aby wyrazić geograficzny system, który łączył razem wybrzeża i wyspy w powszechną sferę interakcji morskich. Jest to całkiem świeże wyrażenie poglądu, że istniały liczne związki przez Kanał La Manche. Wolfgang David w 1997 r. w przekonujący sposób wyraził teorię, że istniały ścisłe związki między wzorem spirali na egejskich obiektach z okresu grobu szybowego i wzorami na kościach i metalach odkrywanych w Kotlinie Karpackiej. Podczas gdy w większości przypadków nie ma dokładnego datowania, kiedy wzór spirali mógł pojawić się na obiektach, na których obszarach zostały odkryte, traktowane jako całość, można je wziąć za dowód ruchu obiektów i wzorów na europejskim kontynencie. Nie chodzi tylko o związki między światem śródziemnomorskim a kontynentalną Europą. Wiele związków dostrzega się także w formach obiektów odkrywanych w różnych regionach kontynentu. Przykładem może być artefakt bęben Balkakra, który wykazuje bliskie związki zarówno technologiczne (proces wytwórczy), jak i symbolizm między Kotliną Karpacka, gdzie prawdopodobnie został wytworzony, a obszarem nordyjskim, gdzie został odkryty. Ten ciekawy obiekt przywołuje na myśl całą serię artefaktów, w tym mieczy z nordyjskiego wczesnego brązu, które wydają się blisko związane, jeśli nie wywodzą się bezpośrednio z Kotliny Karpackiej. Studia wielu indywidualnych przykładów przypadków ujawniają szerokie rozprzestrzenienie się poszczególnych typów artefaktów. Innymi słowy istniały kanały dystrybucji tych obiektów, przez które obiekty te przepływały. Nie ulega wątpliwości, że ten przepływ umożliwiały istniejące związki społeczne. Ludzie transportowali te obiekty nie 
tylko w celu handlowym, lecz także w wyniku mobilności migracji. Pierwotnie studia tego zjawiska ograniczono do okresu kultury pucharów dzwonowatych, w tym jej występowania w południowych Niemczech czy też w południowej Anglii, gdzie tak zwany łucznik z Amesbury wywodzony był z centralnej Europy. Przyjęto też w studiach cmentarzyska z Neckarsulm, że wśród 38 pochowanych tam osób (wszyscy to młodzi mężczyźni), 12 miało inne dane izotopowe niż występujące w lokalnej strefie. Prawdopodobnie urodzili się gdzie indziej i przeprowadzili się na badany obszar, gdzie zmarli. Podobnie takie same studia dokonane na cmentarzysku w Singen, w pobliżu Konstancji nad Jeziorem Bodeńskim, nie wykazały żadnych śladów mobilności. Dane izotopowe można wspierać studiami artefaktów w określonych kontekstach. Jockenhövel wydzielił zjawisko, które nazwał „obcymi kobietami” (,Fremde Frauen”), czyli grupę kobiet, która po ślubie przenosiła się do osady małżonka do sąsiedniej grupy, a definiował ją na podstawie charakterystycznych ozdób stroju odkrywanych w pochówkach. Chodzi tu o tożsamość jednostkową, ale co jest w tym studium ważne, to wielkość grupy, która wykorzystywała taką samą ornamentykę, zaś obszar, na jakim występowała to około $100 \mathrm{~km}^{2}$ wraz z peryferią na dalsze $50 \mathrm{~km}$ od centrum. Sugestie, że można badać mobilność entuzjastycznie podjęło wielu badaczy, na przykład w studiach kurhanów na Grosse Heide w Ripdorf w dolnej Saksonii. Potencjał tego typu analiz jest oczywisty, szczególnie jeśli można go prowadzić razem $\mathrm{z}$ analizami stałych izotopów.

Kolejną uwagą podniesioną przez Anthony'ego Hardinga w jego krytyce aplikacji modelu systemu-świata do archeologii jest podkreślenie, że aby pokazać, że związki między poszczególnymi regionami Europy były systemowe (czyli tworzyły system-świat), nie należy tylko ograniczać się do stwierdzenia, że one istniały. Musi istnieć przekonanie, że zarówno w centrum, jak i na peryferii istniała wiedza wzajemna na ich temat oraz że to centrum było dominujące i wywierało wpływ na peryferie. Następnie wiedza powinna obejmować także to, że wymiana powoduje społeczną i ekonomiczną zmianę oraz że istniały cykle relatywnego wzrostu i rozkwitu oraz następnie upadku. Najważniejsze jest to, że wszystkie te elementy były w systemie-świecie ze sobą wzajemnie powiązane.

Zdaniem Anthony’ego Hardinga Immanuel Wallerstein w 1974 r. był zainteresowany m.in. pojawieniem się kapitalizmu we wczesnonowożytnym świecie, sformułował przy tym założenie, że handel dał w rezultacie zysk dla tych, którzy brali w nim udział. Zdaniem A. Hardinga ten aspekt nie ma przełożenia na pradzieje, chociaż badając świat prahistoryczny, można wziąć pod uwagę takie problemy, jak wzrost prestiżu i statusu.

Udowodnienie na tym poziomie interakcji w pradzieje, chociaż jest ona kluczowa dla debaty na temat modelu centrum-peryferii, nie jest wcale takie prosto, jak to często przyjmowano w badaniach. Dzieje się tak, ponieważ nie istnieje tylko jeden sposób interpretowania danych archeologicznych. Są alternatywne sposoby wizualizowania społeczeństw pradziejowych Europy. Ważne jest wzięcie pod uwagę skali 
społeczności na różnych etapach przeszłości, a także, jeśli to możliwe, określenie, w jakim stopniu były one otwartymi systemami. Aby to uczynić, potrzebna jest informacja $\mathrm{z}$ badań osadniczych przeprowadzonych na dużą skalę, razem z obserwacjami na temat pochodzenia artefaktów odrywanych zarówno w kontekście osadniczym, jak i w kontekście cmentarzysk. Współczesne techniki stosowane w archeologii są w stanie dostarczyć takie dane. Takie studia już rozwiązały wiele problemów dotyczących produkcji pradziejowej i dystrybucji artefaktów, jak również kontekstualne badania artefaktów dały w rezultacie znaczące informacje na temat gender i tożsamości zarówno grupowej, jak i jednostkowej.

Studia kontekstualne są ważne także z innych powodów. Pierwszy z nich związany jest $\mathrm{z}$ silną opozycją wobec teorii systemów-światów i jej aplikacji w archeologii. Chodzi o zanegowanie autonomii uznanych za peryferyjne społeczności w sposobie myślenia współczesnych obserwatorów. Jeżeli założymy, że peryferie były zależne od centrum, a także zawdzięczały swój społeczny i ekonomiczny rozwój centrum, wówczas stają się one porównywalne do kukiełki na sznurku pociąganej przez elity z centrum. Takie same obiekcje jak Anthony Harding, sformułował pod tym względem również Dietler w 1998 r. oraz Joseph Maran w 2011 r. Nie ma żadnych powodów, aby w archeologii przyjmować istnienie takiej zależności. Takie założenie jest nieuzasadnione zdaniem przeciwników teorii systemów-światów.

Badacze także twierdzą, że postrzeganie Europy epoki brązu jako systemu z rozwiniętym centrum i zależnymi, nierozwiniętymi peryferiami wynika częściowo już z tradycyjnych obserwacji archeologicznych. Jest to szczególna perspektywa wynikająca $\mathrm{z}$ analiz rozwiniętej technologii, społeczeństw i gospodarek wschodniego basenu Morza Śródziemnego oraz Egei. Częściowo wynika to z faktu, który Herik Thrane nazwał w 1990 r. „fascynacją Mykenami”. Chodzi dokładnie w tym zjawisku o to, że wspaniałość kultury minojskiej i mykeńskiej Grecji przyciąga obserwatorów i mają oni nadzieję, że te cuda rozchodziły się do nawet najciemniejszych stref Europy. Podobną uwagę w odniesieniu do klasycznej Grecji poczynili Whitehouse i Wilkins w 1989 r.

Inną przyczyną postrzegania Europy epoki brązu jako wielkiego systemu jest potrzeba wielkiej narracji, która opowiadałaby jedną wspólną historię o epoce brązu. Niestety większość z założeń o powiązaniach nie tylko handlowych jest zdaniem Anthony'ego Hardinga po prostu spekulacjami niepopartymi dowodami archeologicznymi.

Zdaniem Anthony'ego Hardinga zwolennicy teorii systemów-światów formułują kolejne dwa założenia: centrum wywołuje zmianę społeczną zachodzącą w peryferii, zmiany te mają cykliczną naturę. Jego zdaniem również w archeologii tradycyjnej powstało w ostatnim czasie wiele prac na temat zmian społecznych, które jako podstawę analizy mają studia cmentarzysk. Zdaniem Hardinga część tych prac jest wysoce spekulatywna. Na pewno można stwierdzić wzrastający wraz z upływem czasu stopień złożoności społecznej na podstawie darów grobowych w epoce brązu. Nie 
tylko chodzi o ilość artefaktów w grobach, ale i o kombinacje, w jakich się pojawiają, co może wskazywać i pomagać w identyfikacji grobów wojowników, rzemieślników, szamanów i wodzów oraz innych. Mamy także informacje na temat pokrewieństwa, gender i tożsamości jednostkowej. Krok w stronę złożoności społecznej został uczyniony w drugiej połowie drugiego tysiąclecia p.n.e. Wielu badaczy tradycyjnych dostrzega przyczyny tego zjawiska w lokalnych okolicznościach, które także ich zdaniem umożliwiały rozwój handlu i wymiany ułatwiających nabycie zaawansowanych technologii w owym czasie. Najbardziej obserwowalnym zjawiskiem zmiany struktury społecznej, zdaniem Hardinga, jest pojawienie się osad ufortyfikowanych w środkowej i późnej epoce brązu. Ich rozprzestrzenienie terytorialne sugeruje istnienie quasi-politycznych jednostek i organizacji, które w epoce żelaza doprowadzają do zdefiniowania terytoriów plemiennych, co jest ukazane w pracach starożytnych autorów. Nie ma żadnych powodów, które pozwoliłyby nam przypuszczać, że te zmiany społeczne obserwowane przez archeologów epoki brązu byłyby rezultatem kontaktów dalekosiężnych między południem a północą Europy. Raczej jego uwarunkowania, czyli wzrost populacji i pojawienie się elit i wodzów jest zjawiskiem lokalnym w społecznościach około 1200 r. p.n.e.

Kristiansen zaobserwował cykle rozwojowe, kiedy porównywał sekwencje rozwojowe basenu Morza Śródziemnego z Europą kontynentalną. W tej obserwacji mówił o hiatusach i przerwach, jako przykład może służyć koniec fazy tell na Węgrzech pod koniec okresu Koszider, kiedy to pojawiły się skarby czy też koniec i zanik osadnictwa jeziornego w Szwajcarii w środkowym brązie oraz jego ponowne pojawienie się w późnym brązie. Przykładem jest też pojawienie się kultur pól popielnicowych. Zdaniem Hardinga problem ten nie dotyczy archeologicznych artefaktów, ale sfery naszej interpretacji braku artefaktów, problemu, jak my tłumaczymy dane. Na przykład cykle budowy osad nadjeziornych w Szwajcarii są thumaczone zmianami klimatu i wzrostem poziomu wód $\mathrm{w}$ jeziorach w połowie drugiego tysiąclecia p.n.e. Wyjaśnienie może być bardziej złożone, jeśli pod uwagę weźmiemy szerszy obszar i zanik osad nadjeziornych zostanie zaobserwowany razem ze wzrostem wzorów osadniczych $\mathrm{w}$ dolinach górskich. Podobnie jest $\mathrm{z}$ końcem konstrukcji typu tell na Węgrzech, czemu towarzyszy horyzont skarbów brązowych w stylu Koszider, co także próbuje się wyjaśniać przez działania ludzkie, na przykład obcej inwazji. Nie można jednak zapominać o środowiskowych uwarunkowaniach zmian osadnictwa. Zdaniem Anthony'ego Hardinga nigdy nie ma jednej przyczyny wyjaśniania zmiany wzorów osadniczych.

Uwagę badaczy epoki brązu przyciąga pojawienie się kultur pól popielnicowych w XIII w. p.n.e. Zjawisko to obejmuje większość Europy. Kimming w 1964 r. związał pojawienie się tej kultury w Europie z najazdem ludów morza na basen Morza Śódziemnego. Bouzek zaprezentował mapę ukazującą upadek liczby osadnictwa w Grecji razem z towarzyszącym jej wzrostem osadnictwa w Europie kontynentalnej. Dla tego okresu archeolodzy mają całe serie dat radiowęglowych zamykających 
się w okresie od 3100 do 2900 r. p.n.e., sugerujących, że w tym okresie zaszła cała seria wydarzeń. Nie wiadomo, czy kultury pól popielnicowych reprezentują przybycie nowych ludów, jak wielu twierdziło. Istotne jest jednak to, że jakieś bliżej nieznane wielkie wydarzenia zachodziły wówczas na kontynencie. Zwolennicy teorii systemów-światów widzą w tych danych dowód na zaistnienie systemu-świata epoki brązu, lecz zdaniem Hardinga nie ma żadnych dowodów na to, że zjawiska te były częścią jakiegoś cyklu rozwojowego. Raczej mogło to być zjawisko pojedyncze, które wywołało głębokie konsekwencje w rozwoju kulturowym całego kontynentu.

Podważywszy możliwość analizowania cykliczności zmian, Anthony Harding poddaje też w wątpliwość możliwości obserwacji sieci wymiany tworzących system-świat. Zauważa, że obserwacje sieci wymiany były czynione $\mathrm{w}$ archeologii jeszcze zanim teoria centrum-peryferii weszła w życie w socjologii. Metody wizualizacji sieci wymiany są ważne jako model obrazowania interakcji w świecie starożytnym na takim samym poziomie, jak wizualizowanie interakcji w świecie współczesnym. Sieci stały się bardzo popularną metodą w różnych naukach, niosąc ze sobą specyficzny język analizy i terminy badawcze. Anthony Harding uważa, że ważne są tu prace Latour z 2005 r., zwłaszcza jego teoria aktora-sieci (,Actor-Network Theory"). Do świata starożytnego udanej aplikacji tej teorii dokonał Knappett w 2008 i 2011 r. Na gruncie skandynawskim przejęli go w 2012 r. Anfinset i Wrigglesworth. Teoria systemów-światów to dedukcyjne ujęcie, którego celem jest identyfikacja interakcji na dużym obszarze. Natomiast omówione wyżej metody wyróżniania sieci interakcji opierają się na małej skali, szukają powiązań na poziomie jednostek. Kontrast miedzy obu metodami jest zdaniem Anthonyego Hardinga dramatyczny. Jego zdaniem metody sieci interakcji są lepsze, ponieważ są prawdziwsze wobec danych, rozpoczynają od danych archeologicznych i budują model indukcyjnie, jakby patrzeć od dołu, od źródeł. Jest to lepsze podejście niż narzucanie gotowego schematu z góry, jak to czyni teoria systemów-światów.

Teorię systemów-światów Kristiansen i Larson wykorzystali w 2005 r. do analizy indywidualnych danych. Identyfikowali na jej podstawie możliwe związki między danymi, następnie wyizolowali skupiska w sieci, w których te badane interakcje zachodziły. Zdaniem A. Hardinga K. Kristiansen podczas gdy deklaruje metodę dedukcyjną i patrzenie z góry w dół, tak naprawdę stosuje kontekstualne podejście do danych i indukcję w swoich badaniach. Uzasadnił on istnienie systemu-świata przez studia wzorów dystrybucji tych archeologicznych artefaktów, które same w sobie nie są warte bliższej uwagi. Kristiansen mimo deklaracji tak naprawdę przeprowadził na szeroką skalę badania kontekstualne artefaktów. Inni zwolennicy teorii systemów-światów, jak na przykład Nick Kardulias, także zaadaptowali metodę proponowaną przez Anthony'go Hardinga. Jego zdaniem, identyfikując pochodzenie artefaktów, warto zidentyfikować warsztaty produkcyjne, czyli miejsca, gdzie analizowane artefakty były wytwarzane i skąd pochodziły, zanim życie tych artefaktów się zakończyło. Jest to niezwykle trudne $\mathrm{w}$ archeologii. A. Harding podaje jako 
przykład stanowisko kultury protovillanov w Frattesinie w dolinie Padu w północnej Italii, gdzie dużo artefaktów wykonanych z takich materiałów, jak kość słoniowa, bursztyn czy szkło było wykańczanych i skąd było eksportowanych w różne strony. Najbardziej możliwa do przeprowadzenia jest obserwacja bursztynu. Wydaje się prawdopodobne, że paciorki bursztynowe typu Tiryns i Allumiere były wytwarzane na tym stanowisku, a dystrybucja tych form wskazuje ważność szlaków morskich. We Frattesinie są dowody na wytwórczość obu typów paciorków razem ze składami surowca bursztynowego. Zaś dystrybucja tego typu paciorków sięga z Italii do Sardynii, Dalmacji, Grecji, Szwajcarii, Bliskiego Wschodu, a nawet Ukrainy. Patrząc w ten sposób Frattesina reprezentuje skupisko, które idealnie położone mogło nadzorować produkcję i dystrybucję bursztynu na północ, południowy-zachód, południe i południowy-wschód. Miasta takie jak Piazza Montfalcone i Lipari mogły, obok Rzymu, być skupiskami w sieci wymiany na zachód i wschód. W Grecji odkryto duże skupisko tego typu paciorków w Kephalonii, co może sugerować następne skupisko w sieci wymiany, podobnie jak Ialysos na wyspie Rodos. Dzisiaj, na podstawie istniejących źródeł, nie można jasno określić, jakim szlakiem paciorki tego typu przenikały na Ukrainę. Być może w przyszłości dalsze przykłady paciorków zostaną odkryte w Egei i sprawa ulegnie rozwiązaniu. Biorąc pod uwagę te dane, Kristian Kristiansen w swojej książce z 1998 r. zobrazował główne centra wymiany w północnej Italii i uważa, że dystrybucja artefaktów sięgała aż do Europy Północnej w formie dystrybucji dwóch rodzajów mieczy. Taka interpretacja jest otwarta na dyskusję na czysto empirycznym gruncie, identyfikacja centrów jest najbardziej dyskusyjna, podobnie jak identyfikacja skupisk. Zdaniem A. Hardinga Kristiansen dokonał wizualizacji sieci interakcji, która mogła charakteryzować ten okres, lecz nie musiała. Co więcej, metoda Kristiansena opiera się na danych archeologicznych, a mianowicie dystrybucji dwóch typów mieczy w Europie i z konkluzji na ten temat Kristiansen wywodzi następne swoje obserwacje skupisk i centrów. A. Harding zauważa, że podobne metody stosowane są nie tylko w teorii systemów-światów, ale przez archeologów na szeroką skalę.

Aby zrozumieć naturę interakcji w epoce brązu, trzeba je najpierw skontekstualizować, co znaczy rozumieć naturę lokalnych społeczności, w obrębie których zachodził ruch artefaktów. Warto, aby, zanim się to uczyni, przyjrzeć się artefaktom w ich naturalnym kontekście, w grupach innych artefaktów, w osadach i w kontekstach grobowych, sprawdzając wzory rozprzestrzeniania artefaktów na danym obszarze, w badanym regionie. Taka metoda jest sprawdzona jako dająca szczegółowy obraz życia i śmierci w poszczególnych społeczeństwach. Przy stale narastających danych pochodzących z nowych wykopalisk jest metodą, na której podstawie można uzyskać obraz życia w epoce brązu. Można wskazać na regiony Europy, o których można już wiele powiedzieć na temat życiu społeczeństw: ich osadnictwa, pochówkach, gospodarce, rolnictwie, rzemiośle. Można twierdzić, że takie małe światy to było to, co ówcześni ludzie postrzegali bezpośrednio. Duży system-świat 
był może doświadczany przez nielicznych: kupców, podróżników, władcówwodzów. W tym kontekście wielkie narracje ogólnoeuropejskie są zdaniem A. Hardinga po prostu niepotrzebne, zamiast nich ważne są narracje lokalne, regionalne. Regionalne studia są prostsze, łatwiejsze i dostarczają bardziej szczegółowych danych archeologicznych. Jeżeli jednak zastosujemy model centrum-peryferii, otrzymamy wzór z Europy z kilkoma niezależnymi, nakładającymi się na siebie centrami, każdą z własnymi peryferiami. Można poddać w wątpliwość granice peryferii. Lecz prawdziwym zadaniem jest identyfikacja prawdziwych centrów, bo archeologiczne dane czynią to przedsięwzięcie trudnym do wykonania.

$\mathrm{W}$ następnym artykule zamierzam omówić prace zawarte w tomie 2 Journal of World Systems Research z 1995 r., całkowicie poświęconego aplikacji modelu I. Wallersteina $\mathrm{w}$ różnych poddyscyplinach archeologii, czasopisma i tematyki prawie wcale nieznanej i nierozważanej na gruncie archeologii polskiej.

\section{BIBLIOGRAFIA}

Abu-Lughod J.

2012 Europa na peryferiach. Kęty: Wydawnictwo Marek Derewiecki.

Alexander R.T.

1999 The emerging world-system and colonial Yucatan: the archaeology of core-periphery integration 1780-1847. W: N. Kardulias (red.), World-Systems Theory in Pracice: Leadership, Production and Exchange (s. 103-124). Lanham: Rowman and Littlefield Publishers.

Anfinset N., Wrigglesworth M. (red.)

2012 Local Societies in Bronze Age Northern Europe. Sheffield: J.R. Collis Publication.

Barfield T.

1989 The Perilious Frontier Nomadic Empires and China 221 BC to AD 1757. Cambridge and Oxford: Blackwell.

Berg I.

1999 The Southern Aegean System. Journal of World System Research, 5, s. 475-485.

Blanton R., Feineman G.M.

1984 The Mesoamerican World-System. American Anthropologist, 86, s. 673-682.

Bouzek J.

1994 Late Bronze Age Greece and the Balkans: A Review of the Present Picture. Annual of the British School at Athens, 89, s. 217-234.

Braudel F.

1999 Historia i trwanie. Warszawa: Czytelnik.

Champion T. (red.)

1995 Centre and Periphery. Comparative Studies in Archaeology. London and New York: Routledge.

Czebreszuk J.

2011 Bursztyn w kulturze mykeńskiej. Poznań: Wydawnictwo Poznańskie.

David W.

1997 Altbronzezeitliche Beinobjekte des Karpatenbeckens mit Spiralwirbel- oder Wellenbandornament Und Ihre Parallelen auf der Peloponesen Und In Anatolien In Frühmyke- 
Dietler M.

nischenzeit. W: P.I. Roman (red.), The Thracian World at the Crossroads of Civilisation (s. 247-305). Bucharest: Institutul Roman der Tracologie,

1998 Consumption Agency and Cultural Entanglement. W: J.G. Cusick (red.), Studies in Culture Contact (s. 288-315). Carbondale: IL.

Feinman G.M.

1999 The changing structure of macroregional Mesoamerica: the Classic-Postclassic transition in the Valley of Oaxaca. W: N. Kardulias (red.), World-Systems Theory in Practice: Leadership, Production and Exchange (s. 53-62). New York: Rowman and Littlefield Publishers.

Frank A.G.

1993 Bronze Age World System Cycles. Current Anthropology, 34, s. 383-429.

Frank A.G., Gills K.G. (red.)

1993 The World System: Five Hundred Years of Five Thousands? London: Routledge.

Friedman J., Rowlands M.

1977 Notes towards an Epigenetic Model of the Evolution of Civilisations. W: J. Friedman, M. Rowlands (red.), The Evolution of Social Systems. London: Gerald Duckworth and Co.

Hall T.D., Chase-Dunn C.

1993 The World System-Perspective and Archaeology. Journal of Archaeological Research, 2, s. 121-143.

Harding A.

1984 The Myceneans and Europe. London: Emerald.

Harding A.

2013 World Systems, Core and peripheries in prehistoric Europe. European Journal of Archaeology, 16(3), s. 1-23.

Jockenhövel A.

1991 Raumlische Mobilität von Personen In der mittleren Bronzezeit des westlichen Mitteleuropa. Germania, 69, s. 49-62.

Kardulias P.N.

1999 Multiple Levels In the Aegean Bronze Age World-System. W: P.N. Kardulias (red.), World Systems Theory in Practice (s. 179-201). New York: Rowman and Littlefield Publishers.

Kardulias P.N., Hall T.D.

2008 Archaeology and World-System Analysis. World Archaeology, 50(4), s. 572-583.

Kimming W.

1964 Seevölkerbewebung Und Urnenfelderkultur. W: R.V. Uslar i K.J. Narr (red.), Studien aus Alteuropa (s. 220-283). Köln: Bohlau Verlag.

Knappett C.

2011 An Archaeology of Interaction. Network Perspectives on Material Culture and Society. Oxford: Oxford University Press.

Kohl P.

1987 The Use and Abuse of World Systems Theory: the Case of the Pristine West Asian State. Advances In Archaeological Method and Theory, 11, s. 1-35

Kepecs S., Kohl P.

2003 Conceptualizing macroregional interaction: world-systems theory and the archaeological record. W: M.E. Smith, F.F. Berdan (red.), The Postclassic Mesoamerican World (s. 14-20). Salt Lake City: University of Utah Press. 
Kristiansen K.

1987

Centre and Periphery In Bronze Age Scandinavia. W: M. Rowlands, M. Larsen, K. Kristainsen (red.), Centre and Periphery in the Ancient World (s. 74-85). Cambridge: Cambridge University Press.

Kristiansen K.

1994 The Emergence of the European World System In the Bronze Age. W: K. Kristiansen, J. Jensen (red.), Europe in the First Millenium B.C. (Archaeological Monographs 6, s. 7-30). Sheffield: J.R. Collis Publications.

Kristiansen K.

1998 Europe before History. Cambridge: Cambridge University Press.

Kristiansen $\mathrm{K}$.

2011

Bridging India and Scandinavia. W: T. Wilkinson, A. Sherratt, I.J. Benett (red.), Interweaving Worlds (s. 243-265). Oxford: Oxbow Books.

Kristiansen K., Rowlands M., Larsen M.T. (red.)

$1987 \quad$ Centre and Periphery in the Ancient World. Cambridge: Cambridge University Press.

Kristiansen K., Larsson T.B.

2005 The Rise of Bronze Age Society: Travels, Transmissions and Transformation. Cambridge: Cambridge University Press.

LaLone D.

1994 An Andean World-System: Production Transformations under the Inca Empire. W: E.M. Brumfiel (red.), The Economic Anthropology of the State (s. 17-42). Lanham: Rowman and Littlefield Publication.

Latour B.

2005 Reassembling the Social. Oxford: Oxford University Press.

Maran J.

2011 Lost In Translation: The Emergence of Mycenean Culture as a Phenomenon of Globalisation. W: C. Wilkinson, S. Sherratt, J. Bennet (red.), Interweaving Worlds (s. 282-294). Oxford: Oxbow Books.

Needham S.

2009 Encompassing the Sea: Maritories and Bronze Age Maritime Interactions. W: P. Clark (red.), Bronze Age Connections. Cultural Contact in Prehistoric Europe (s. 12-37). Oxford: Oxbow Books.

O’Brien P.

1994 The central lowland Plains: an overview. W: K.H. Schlesier (red.), Plains Indians A.D. 500-1500: The Archaeological Past of Historic Groups (s. 199-223). Ocklahoma: University of Ocklahoma Press.

Piles R.A., Whitecotton J.W.

1979 The Greater Southwest and Mesoamerican World System. An Explanatory Model of Frontier Relationships. W: W. Savage, S. Thompson (red.), The Frontier Comparative Studies (vol. 2, s. 105-121). Norman: University of Oklahoma Press.

Peregrine P.N., Feinman P.N. (red.)

1998 Pre-Columbian World-system. Madison: Prehistory Press.

Polanyi K.

1944

The Great Transformations. Boston: Beacon Press

Polanyi K.

1957 Trade and Markets an the Early Empires. Glencoee Illinois: The Free Press.

Radina F., Recchia G. (red.)

2010 Ambra per Agamemnone. Bari: Adda Editore. 
Scarre C., Healy F. (red.)

1993 Trade and Exchange in Prehistoric Europe: Proceedings of a Conference Held at the University of Bristol, April 1992. Oxford: University of St Andrews.

Sherratt A.

1995 What Would a Bronze-Age World System Look like? Journal of European Archaeology, 1(2), s. 1-57.

Sherrat A., Sherrat S.

1991 From luxuries to commodities: the nature of Mediterranean Bronze Age trading systems. W: N.H. Gale (red.), Bronze Age Trade in the Mediterranean (s. 351-286). Jonsered: P. Astroems Vorlag.

Sherrat A.

1997 Economy and Society In Prehistoric Europe: Changing Perspectives. Edinburgh: Edinburgh University Press.

Schauer P.

1983 Orient im spätbronze- Und früheisenzeitlichenOccident. Jahrbuch des Römisch-Germanischen Zentralmuseums Mainzt, 30, s. 175-194.

Schauer P.

1984 Spuren minoisch-mykenischen und orientalischen Einflusses in atlantischen Westeuropa. Jahrbuch des Römisch-Germanischen Zentralmuseums Mainz, 31, s. 137-186.

Schauer P.

1985 Spuren orientalischen und ägäischen Einflusses im bronzezeitlischen Nordischen Kreis. Jahrbuch des Römisch-Germanischen Zentralmuseums Mainz, 32, s. 123-195.

Schortman E.M., Urban P.A.

1999 Thoughts on the periphery: the ideological consequences of core-periphery relations. W: P. Nick Kardulias (red.), World-Systems Theory in Practice: Leadership, Production and Exchange (s. 125-152). Lanham: Rowman and Littlefield Publishers.

Schumpeter J.

1960 Teorie rozwoju gospodarczego. Warszawa: Wydawnictwo Naukowe PWN.

Starnawski M., Wielgosz P.

2007 Przedmowa do wydania polskiego. W: I. Wallerstein, Analiza systemów-światów. Wprowadzenie (s. VI-VII). Warszawa: Dialog.

Stein G.

1999 Rethinking World-Systems. Tucson: The University of Arizona Press.

Thrane $\mathrm{H}$.

1990 The Mycenean Fascination. W: P. Schauer (red.), Orientalisch-ägische Einflusssein der europäischen Bronzezeit (Monographien der RGZM, s. 165-179). Bonn: Verlag des Römisch-Germanischen Zentralmuseum.

Wallerstein I.

1974 The Rise and Future Demise of the World Capitalist System: Concepts for Comparative Analysis. Comparative Studies in Society and History, 16(4).

Wallerstein I.

1976 The Modern World System: Capitalis Agriculture and the Origins of the European World Economy in the $16^{\text {th }}$ Century. New York: Academic Press.

Wallerstein I.

1979 The Capitalist World-Economy. Cambridge: Cambridge University Press.

Wallerstein I.

1980 The Modern World Systems 2: Mercantilism and the Consolidation of the European World Economy 1600-1750. New York: Academic Press. 
Wallerstein I.

1984 The Politics of the World-Economy. Cambridge: Cambridge University Press.

Wallerstein I.

1989 The Modern World System 3: The Second Great Expansion of the Capitalist World Economy 1730-1840. San Diego: Academic Press.

Wallerstein I.

1991 Geopolitics and Geoculture. Cambridge: Cambridge University Press.

Wallerstein I.

1995 After Liberalism. New York: The New Press.

Wallerstain I.

1995 Historical Capitalism with Capitalist Civilisation. London and New York: Verso.

Wallerstein I.

1998 Utopistics. New York and London: The New Press.

Wallerstein I.

1999 Wyzwania wobec nauk spolecznych u progu XXI wieku. Kraków: Universitas.

Wallerstein I.

2000 The Essential Wallerstein. New York: The New Press.

Wallerstein I.

2001 Unthinking Social Science: The Limits of Nineteenth-century Paradigms. Philadelphia: Temple University Press.

Wallerstein I.

2001 Unthinking Social Science. Philadelphia: Temple University Press.

Wallerstein I.

2003 The Decline of American Power. New York and London: The New Press.

Wallerstein I.

2004 Koniec świata jaki znamy. Warszawa: Wydawnictwo Naukowe Scholar.

Wallerstein I.

2004 The Uncertainities of Knowledge. Philadelphia: Temple University Press.

Wallerstein I.

2007 Analiza systemów-światów. Wprowadzenie. Warszawa: Dialog.

Wallerstein I.

2011 The Modern World-Systems: Centrist Liberalism Triumphant 1789-1914. University of California Press: Los Angeles.

Wallerstein I.

2007 Analiza systemów-światów. Wprowadzenie. Warszawa: Dialog.

Wallerstein I., Arrighi G., Hopkins T.K.

1989 Antisystemic Movements. London and New York: Verso.

Wallerstein I., Balibar E.

1991 Race, Nation, Class. London and New York: Verso.

Wallerstein I., Hopkins T.K.

1996 Trajectory of the World Systems 1945-2025. Journal of World System Research, 6(2).

Warburton D.A.

2011 What might the World Age World System Look Like? W: T. Wilkinson, S. Sherratt, J. Bennet (red), Interweaving Worlds: Systemic Interactions in Eurasia $7^{\text {th }}$ to $1^{\text {st }}$ Millenia $B C$ (s. 120-134). Oxford: Oxbow Books.

Whitehouse R., Wilkins D.

1989 Greeks and Natives In South-East Italy. W: T. Champion (red.), Centre and Periphery. Comparative Studies in Archaeology (s. 102-126). London: Routledge. 
Wilkinson D.

2004 The Power Configuration Sequence of the Central World System 1500-700 p.n.e. Journal of World System Research, 10, s. 655-720.

Żakowski J.

Koniec. Warszawa: Wydawnictwo Sic!

\section{IMMANUEL WALLERSTEIN'S CENTRE - PERIPHERY THEORY AND ITS RECEPTION IN ARCHAEOLOGY}

\section{Summary}

The proposed article presents the World-System Theory, which is also called the Centre - Periphery Model, and its application and usefulness in archaeology. This article focuses only on the World-System Theory; the World-System Analysis an and the second issue of the Journal of World Systems Research from 1995, which was devoted to the archaeological implication of Immanuel Wallerstein's theory to archaeology, will be discussed elsewhere.

This paper looks at the background to the Theory, its emergence at the beginning of the 1970s and its influence on archaeological works, particularly on the scholarly activity of Kristian Kristiansen and Andrew Sherrat.

As an example, I present some statements concerning the Bronze Age as an era that witnessed very sophisticated, multiple exchange relations connecting remote regions of Europe. Andrew Sherrat created the model of the Bronze Age World System. He proposed the chronology of the Bronze Age completely different from the well-known periodization of the period and as the implications, he created a model showing such economic processes as the accumulation and distribution of wealth, redistribution and inflation. These issues had been hitherto overlooked by archaeology. In his 1998 book, Kristian Kristiansen presents economic, political and cultural centres in northern Italy, producing two types of swords. He supposes that two trade waves reached northern Europe, where the swords were found. He investigates a sophisticated net of exchange and trade existing in Bronze Age Europe.

I present also the critique of the World-System Theory and its application in archaeology by Anthony Harding. He does not propose a total criticism of the World Systems Theory, but only supposes that the long term exchange was only felt and experienced by small groups of people, notably travellers, merchants, kings or people in power. However, most important for an archaeological investigation should not be the long term exchange but regional trade and regional routes, which were felt and experienced by ordinary people.

The application of World Systems Theory is uncommon in archaeology. I think that the issues discussed in this article can shed new light on well-known facts. I am sure that archaeologists should not only discover artefacts but also develop theories and formulate models, without which archaeology cannot move forward. 